\title{
Evaluation of adoption rate of frozen sexed semen artificial insemination technology adoption in Palang Village, Tuban Regency, East Java
}

\author{
Rizki Prafitri ${ }^{1)}$, Priyo Sugeng Winarto ${ }^{1)}$, Aulia Puspita Anugra Yekti ${ }^{1)}$, Trinil Susilawati ${ }^{1)}$, \\ Kuswati $^{1)}$ \\ ${ }^{1)}$ Faculty of Animal Science, Universitas Brawijaya \\ Malang, Indonesia
}

Submitted: 14 January 2021, Accepted: 24 March 2021

\begin{abstract}
A research group of Animal Science Faculty of Brawijaya University introduced and implemented Frozen sexed semen Artificial Insemination to 120 beef cattle farmers in Palang Village, Tuban Regency, East Java, from 2017 to 2019. The result of the program reported that the success rate of the technology is quite high, with the birth rate of males claves up to $80 \%$. However, farmers' adoption rate of the technology was relatively low. This research aims to evaluate factors that affected the adoption rate including the technology, characteristics of respondents, and the extension agents. Primary data were collected through a census of 120 farmers involved in the program and in-depth interviews with stakeholders. Secondary data were collected through related documents including reports of the programs, Statistics, and other related documents. This research utilized Quantitative and qualitative analyses. Data of the study indicated that respondents have neutral perceptions of the Frozen Semen Sexing Artificial Insemination. Although male calves relatively have a higher price, more than $50 \%$ of respondents did not expect specific sexing for the calves. In-depth interview data revealed that the success of the Artificial insemination technology is more valuable for the farmers rather than the sexing. Characteristics of respondents and the extension agents played significant roles in the adoption rate of the Frozen Sexed Semen Artificial Insemination technology adoption in Palang Village, Tuban Regency, East Java. Overall, it is important that extensions ensure the technology meet the need of the society and selectively choose respondents to increase the adoption rate of technology adoption.
\end{abstract}

Keywords: Artificial Insemination; Sexed semen; Innovation; Adoption

*Corresponding Author: rizkiprafitri@ub.ac.id 


\section{INTRODUCTION}

Beef cattle is one of the important commodities for Indonesian economics. Indonesia imported red meat from India, Ausralia, and other countries (BPS-Statistics Indonesia, 2020). Statistics Indonesia reported that in 2018, meat production in Indonesia was only 496 thousand tons, while in the same time the demand was more that 660 thousand tons (BPS-Statistics Indonesia, 2020). On the other hand, cattle farmers in Indonesia are interested more in fattening because of the shorter cash flow cycle compare to breeding or rearing farming. This decreased the number of cattle in Indonesia and increased the need for imported beef cattle. Addressing this problem, the team from the Faculty of Animal Science Universitas Brawijaya with Bank Indonesia created Beef Cattle Cluster in Palang Village, Tuban Regency East Java from 2017 to 2019. This program aimed to attract farmers to be interested in breeding farming, and strengthen East Java as the center of cattle beef breeding in Indonesia.

Based on the report program in 2019, the pregnancy percentage using frozen nonsexed semen AI increased from 43,75\% in 2017 to $78,75 \%$ in 2018. Moreover, the use of frozen sexed semen AI also showed positive progress from $65,6 \%$ in 2017 , to $72,5 \%$ in 2018 and $86 \%$ in 2019. In 2019 the program only implemented sexed semen using double straw methods at two different times. However, even though the birth rate of male claves was quite high up to $80 \%$, the program report stated that the adoption rate of the technology and innovation was relatively low (Susilawati, 2019). Previous research done related to the project were only analyze the pregnancy cate and the adoption rate of the technology without further analysis on what factors affecting this.

Therefore, it is important to analyze the factors affecting the adoption rate of cattle farmers to understand the challenges and social problems faced by the community in implementing the technology and innovation provided. The purpose of the study is to evaluate factors affecting the adoption rate including the technology, characteristics of respondents and the extension agents.

\section{MATERIALS AND METHODS Methods}

This research implemented a case study in cattle farming in Palang Village, Tuban Regency, East Java. Case study research involves an analysis of contemporary phenomena in a real-world context (Yin, 2013). Purposive sampling was chosen in this study because the community was acceptors of the program provided by the Faculty of Animal Science and The Central Bank of Indonesia.

Respondents were chosen based on their knowledge and experience related to the purpose of the research (Sarantakos, 2005). 120 cattle farmers who received the program were chosen as respondents in this study. Moreover, in-depth interviews were done with stakeholders related to the program, including farmers, acceptors, nonacceptors, inseminators, community leaders, and local brokers. In-depth interviews were done to disclosure responses and factors affecting cattle farmer's decision to adopt or reject the innovation and information provided.

Secondary data were gathered from literature, reports of the program, statistic data, and other information related to the program. Secondary data played important roles in social research to provide information and supporting primary data collected by researchers (Yin, 2013).

\section{Data Analysis}

Data were analyzed with quantitative and qualitative methods. Quantitative analysis using descriptive analysis was done to three factors, namely (X1) Technology, (X2) Characteristics of respondents, and (X3) The extension agents and their impact on respondents' decision to adopt or reject the innovation (Y). This study utilized an ordinal scale to transform qualitative data 
into quantitative form with Likert Scale: (5) Excellent, (4) Good, (3) Average (4) Fair (5) Poor. Data collected were analyzed with Microsoft Excel using the correlation technique on every score of the questionnaire.

Qualitative analysis was done using descriptive analysis and frequency distributions. Qualitative research relies on 'rigor' as 'reliability' and 'Validity' quantitative research (Liamputtong, 2013). Rigour pays attention to detailed information, understanding, theory, method, and ethical dimensions to elevate the trustworthiness of the research (Walter,
2013). Bryman (2012) identified four points in measuring trustworthiness in qualitative research namely credibility, transferability, dependability, dan confirmability.

\section{Validity and Reliability \\ Validity}

Test Validity is the extent to which the questionnaire accurately measures the data. A questionnaire is valid if it accurately measures what is supposed to measure (Ghozali, 2013). If the result of Test Validity shows $r_{\text {count }}>r_{\text {table, }}$ it means that the questionnaire is valid. On the other hand, the questionnaire is not valid if $r_{\text {count }}<$ rtable.

Table 1. Question list (X1)

\begin{tabular}{lccc}
\hline \multicolumn{1}{c}{ Question (X1) } & r & Validity \\
\hline $\begin{array}{l}\text { I expected male calve by using Frozen Sexed Semen Artifical } \\
\text { Insemination (FSSAI) }\end{array}$ & 0.713 & 0.361 & Valid \\
\hline FSSAI works similar with normal Frozen Artificia Insemination & 0.528 & 0.361 & Valid \\
\hline $\begin{array}{l}\text { FSSAI straws contain similar semen as normal Frozen Artificia } \\
\text { Insemination }\end{array}$ & 0.709 & 0.361 & Valid \\
\hline The result of FSSAI met my expectation & 0.571 & 0.361 & Valid \\
\hline $\begin{array}{l}\text { FSSAI is more expensive compare to normal Frozen Artificial } \\
\text { Insemination }\end{array}$ & 0.534 & 0.361 & Valid \\
\hline Cow Breed used in FSSAI straw met my expectation & 0.769 & 0.361 & Valid \\
\hline I need more information related to the breed used in FSSAI straw & 0.551 & 0.361 & Valid \\
\hline $\begin{array}{l}\text { I don't have self determination to choose the breed used in FSSAI } \\
\text { straw }\end{array}$ & 0.414 & 0.361 & Valid \\
\hline Autonomy to determine the breed used in FSSAI straw will help me & 0.587 & 0.361 & Valid \\
\hline
\end{tabular}

Table 2. Question List X3

\begin{tabular}{lccc}
\multicolumn{1}{c}{ Question (X2) } & $\mathrm{r}_{\text {count }}$ & $\mathrm{r}_{\text {table }}$ & Validity \\
\hline $\begin{array}{l}\text { I (farmer) can use a mobile phone to communicate with the } \\
\text { inseminator. }\end{array}$ & 0.515 & 0.361 & Valid \\
\hline $\begin{array}{l}\text { I chose Artificial Insemination for on time pregnancy schedule of my } \\
\text { cattles }\end{array}$ & 0.755 & 0.361 & Valid \\
\hline I chose AI because it is easier & 0.592 & 0.361 & Valid \\
\hline I chose AI because it is cheaper & 0.670 & 0.361 & Valid \\
\hline I chose AI because it produces good quality calves & 0.631 & 0.361 & Valid \\
\hline I chose AI because it produces higher price of calves & 0.721 & 0.361 & Valid \\
\hline I chose AI because the inseminator helps me & 0.792 & 0.361 & Valid \\
\hline I chose AI because I believe to the government & 0.421 & 0.361 & Valid \\
\hline
\end{tabular}

\section{Reliability}

Reliability indicates the consistency measurement from the questionnaire. A questionnaire has high reliability if produces consistent result over time (Ghozali, 2013). Microsoft Excel was utilized in this research to measure the reliability using productmoment and score of each question. Questionnaire is valid if $t_{\text {count }}>t_{\text {table }}$ (significance 0,05 ) and significance $5 \%$ $(0,05)$. 
Table 3. Reliability test

\begin{tabular}{ccc}
\hline Question & Cronbach's Alpha & Reliability \\
\hline X1 & 0.586 & Reliable \\
\hline X3 & 0.724 & Reliable \\
\hline Y & 0.655 & Reliable
\end{tabular}

\section{RESULT AND DISCUSSION}

Result and discussion of the study focused on the characteristics of innovation, respondent characteristics, and extension agents.

\section{Characteristics of Innovation}

The main purpose of Frozen Sexed Semen Artificial insemination (FSSAI) innovation is to increase the chance of a specific sexing on cattle birth (Susilawati, 2014). For example, it assumes that beef cattle farming expected more male cattle because of the higher price and growth scale compare to female cattle. On the other hand, dairy farming expected more female calves to be replacement heifers.

However, data of this research showed neutral responses from respondents related to the use of FSSAI they have implemented through the program. $70 \%$ of respondents or more than $58 \%$ of acceptors provided neutral answers related to their reason for using FSSAI to increase the chance of male cattle birth. Moreover, the neutral answer was also given by respondents related to the use of FSSAI straws, breeds of cattle they expected, and price of FSSAI technology. The result can be seen in table 4 .

Table 4. Respondents' opinion related to the use of FSSAI

\begin{tabular}{|c|c|c|c|c|c|}
\hline Question & 1 & 2 & 3 & 4 & 5 \\
\hline $\begin{array}{l}\text { I expected male calve by using Frozen Sexed Semen Artificial } \\
\text { Insemination (FSSAI) }\end{array}$ & 0 & 9 & 70 & 37 & 4 \\
\hline FSSAI works similar with normal Frozen Artificial Insemination & 0 & 19 & 59 & 41 & 1 \\
\hline $\begin{array}{l}\text { FSSAI straws contain similar semen as normal Frozen Artificial } \\
\text { Insemination }\end{array}$ & 0 & 18 & 65 & 37 & 0 \\
\hline The result of FSSAI met my expectation & 0 & 13 & 64 & 41 & 2 \\
\hline FSSAI is more expensive compare to normal Frozen Artificial Insemination & 0 & 10 & 65 & 43 & 2 \\
\hline Cow Breed used in FSSAI straw met my expectation & 0 & 24 & 68 & 25 & 3 \\
\hline I need more information related to the breed used in FSSAI straw & 1 & 13 & 75 & 29 & 2 \\
\hline I don't have self determination to choose the breed used in FSSAI straw & 0 & 16 & 78 & 25 & 1 \\
\hline Autonomy to determine the breed used in FSSAI straw will help me & 0 & 11 & 68 & 40 & 1 \\
\hline
\end{tabular}

1. Strongly disagree; 2. Disagree; 3. Neutral; 4. Agree; 5. Strongly agree

The result of the study provided contradictory responses from respondents compare to the prediction of introducing FSSAI technology to cattle beef farmers. This data was confirmed by the in-depth interview result. In-depth interview results informed that expecting a specific sexing was not the main purpose of using Artificial Insemination. A Farmer stated that he prefers a higher pregnancy rate rather than a specific sexing by using Artificial Insemination Technology. Another respondent added that he would rather a successful AI no matter the sexing of the calves compares to expecting male calves by using FSSAI technology, but the pregnancy rate is low. The community leader informed that the use of FSSAI is could causing problems on the ecosystem balance if everyone expects male calves. Instead, they do need female cattle for heifers. The data showed opposite results with Wahjuningsih (2019) that farmers' interest to use FSSAI is high because of the higher price of male calves.

A previous study confirmed that the pregnancy rate was quite high (Susilawati, 2019). In 2018, the percentage of pregnancy rate was up to $80 \%$ or 64 cows were pregnant using Non-Sexed Frozen Artificial 
Insemination, while only $70 \%$ or 56 cows were pregnant by using FSSAI technology. Based on the survey data in 2019, calves born using the Non-Sexed and Sexed Artificial Insemination proofed that the number of male cattle born using the FSSAI technology was higher than Non-Sexed one. Data showed that 46 male calves or $82,1 \%$ male calves were born using the FSSA technology, but in contrast, only 34 cows or $53,1 \%$ male calves were born using the NonSexed Frozen Artificial Insemination.

Result of previous study (Susilawati, 2019) confirmed that the use of Non-Sexed Frozen Semen Artificial Insemination had a higher pregnancy presentation rate compare to the FSSAI. Even though, the use of FSSAI technology increased the percentage of male calves' birth compare to the NonSexed one. The data showed that using the FSSAI technology increase the chance to have a male calf, but the chance to get pregnant is much lower than the Non-sexed one. The preference of cattle farmers to focus on the pregnancy rate rather than the sexing of calves can be understood. This is strongly related to the efficiency of cattle farming in the community. The fail of the Artificial Technology process is costly for farmers. Inline with this, (Afiati \& Said, 2013) the successful of AI affecting farmers' interest to adopt the technology.

The success of Artificial Insemination technology especially Frozen Sexed Semen should enhance the awareness of stakeholders including researchers, the National AI Centre as the producer of frozen semen, the government, and also inseminators. Susilawati (2013) stated that factors are affecting the success of AI implementation are the quality of frozen semen, inseminators, farmers and female physiology.

Each factor and stakeholders play important roles in the success of Artificial insemination implementation in Indonesia. For example, for the first factor, the quality of frozen semen there are stakeholders involves including researchers, the National AI center, and the government. Researchers play a role to explore the technology and separating spermatozoa to provide a higher chance of specific sexing of calves expected.

The National AI center is the formal institution that has the license to produce and distribute frozen semen and responsible to ensure the quality of frozen semen produced and marketed. The National AI center should guarantee that the straw produced by the institution has fulfilled the minimum standard of spermatozoa contained, including Sexed and non Sexed Semen Artificial Insemination.

The government, represented by the Livestock Service plays important role to distribute frozen semen to farmers. The Livestock Service also has the responsibility to regularly checks the quality of frozen semen distributed to farmers through an inseminator. They should ensure that frozen semen straws were delivered to and accepted by farmers in good condition and fulfill the minimum standard spermatozoa. Moreover, the Livestock Service also has the responsibility to update the knowledge and skill of inseminators in the area.

Inseminators have an important role to provide Artificial Insemination services to farmers (Jemal \& Lemma, 2015). Inseminators could choose the best method used based on the condition of acceptors. Some methods can be used by the inseminator, including the position of semen deposition in the ovaries of the cattle. The technology of Artificial Insemination implementation develops over time. Therefore, inseminator needs to update and improve their knowledge and skills in providing Artificial Insemination services to farmers and increase the success of AI implementation.

Farmers' ability to detect the estrus of cows has a relationship to the time of the inseminator for AI service. The best time to do insemination is the key to the success of AI implementation (Susilawati, 2013). Farmers, should aware of the estrus sign of the cattle including anxiety, swelling, and redetermines vulva. Moreover, good farming management is also important to 
determine the success of AI implementation, including cleanliness and feeding management. Although there is a strong relationship between Body Condition Score with the success of Artificial insemination (Ervandi, Ihsan, Wahjuningsih, Yekti, \& Susilawati, 2020), data of the research (Susilawati, 2019) showed that most farmers in the community did not provide good nutritious feed for the cattle, breastfeeding for estrus time, AI process, pregnancy time, post parturition, and breastfeed, in which cattle have a higher nutritious feed. Therefore, in most cases, some cattle were experiencing malfunction nutrition and causing the reproduction organ and hormone did not to function well causing the failure of AI. The failure of AI is causing inefficient cattle farming and decrease farmers' income.

\section{Respondent characteristics}

Based on data of the study, more than $50 \%$ of respondents were more than 51 years old. This indicates that most of the acceptors of the FSSAI program were categorized as less productive age. In consequence, this affected the innovation adoption rate of respondents. Moreover, in less productive age, farmers tend to have less courage to try new technology or innovation compare to younger farmers in productive age. Farmers categories in less productive age will adopt an innovation if it is already proven. Considering the age classification of farmers, it is important to selectively choose the respondents to introduce or implement an innovation or technology to farmer communities. Choosing respondents from the productive age group (15-54 years old) will increase the success of innovation adoption in the community. Moreover, they can be the agent of change in the community to diffuse the innovation or technology to the rest of the community. In contrast, choosing respondents from less productive could be an obstacle to introducing innovation or technology.

The relationship between age and innovation adoption remains debatable (Adegbola \& Gardebroek, 2007). Old farmers usually have more privileges such as capitals, land availability, and family size, which these factors could help them to adopt innovation faster than young farmers (Sall, Norman, \& Featherstone, 2000). Experience, knowledge, and skills increase according to age (Eddy, Roessali, \& Marzuki, 2012). In contrast, other studies showed that aged farmers had less motivated to develop farming, while young farmers were interested to change and adopt technology (Setiana, Saleh, Nugroho, \& Lana, 2020). Supporting this, the result of this study showed that the age of respondents affected the ability of innovation adoption. Sirajudin et al. (2018) stated that farmers more than 50 years are mostly categorized as repellent groups. Respondents' age of the study can be seen in table 5 .

Table 5. Respondent ages

\begin{tabular}{ccc}
\hline Age range & Number of respondents & Percentage $(\%)$ \\
\hline$<30$ & 1 & 0.83 \\
$>61$ & 12 & 10.00 \\
$31-40$ & 12 & 10.00 \\
$41-50$ & 33 & 27.50 \\
$51-60$ & 62 & 51.67 \\
\hline Total & 120 & 100.00
\end{tabular}

Another characteristic of the respondent that affecting the adoption rate was the education level. Similar to the age of respondents, the education level of farmers and its impact on the adoption level differs for every case. Some previous research found that education level was not significantly related to the adoption rate of innovation (Setiana et al., 2020; Sirajuddin, Sudirman, Bahar, Al Tawaha, \& Al Tawaha, 2018). However, the higher level of education had higher innovation adoption 
levels compare to farmers with a lower level of education (Soekartawi, 2008). Murwanto (2008) stated that the education level of farmers is a crucial aspect of human resource development.

Data from the study showed that almost $50 \%$ of respondents were completed at the elementary level, and more than $20 \%$ did not even complete the elementary level. Moreover, in this case, study most respondents were not only had a lower education level but also categorized as less productive age farmers. These factors strongly affected the low level of technology adoption. Education level of respondents can be seen in table 6 .

Table 6. Education Level of Respondents

\begin{tabular}{lcc}
\hline \multicolumn{1}{c}{ Education level } & Respondents & Percentage $(\%)$ \\
\hline Accomplished higher Education level/Academy/University & 1 & 0.83 \\
Accomplished Elementary School level & 59 & 49.17 \\
Accomplished Senior High School Level & 7 & 5.83 \\
Accomplished Junior High School Level & 26 & 21.67 \\
Not accomplished Elementary School & 27 & 22.50 \\
\hline Total & 120 & 100.00 \\
\hline
\end{tabular}

Data from the study showed that cattle farming is not the main profession of respondents. Almost $50 \%$ of the total respondents' occupation was rice farmers. It is not surprising if respondents did not put energy and effort into their cattle farming. Moreover, the number of family labor is affecting motivation to increase cattle production (Roessali, Masyhuri, Nurtini, \& Darwanto, 2011). Motivation level positively correlated with the adaption of technology (Guntoro \& Priyadi, 2013). The higher motivation level of the farmer will increase the farmers' adoption rate of technology.

Confirmation related to the main occupation of respondents gathered during the in-depth interview with stakeholders. The community leader confirmed that cattle beef farming is the only side job for most farmers in the community. The purpose of cattle farming for most respondents was for savings and cattle could be sold at any time they need extra money for the family. Cattle Farming experience duration can be seen in Table 7.

Table 7. Cattle Farming Experience Duration

\begin{tabular}{lccc}
\hline & Duration & Respondents & Percentage $(\%)$ \\
\hline$>15$ years & 35 & 29.17 \\
11 to $<14$ years & 52 & 43.33 \\
5 to $<6$ years & 4 & 3.33 \\
7 to $<10$ years & & 29 & 24.17 \\
\hline & Total & 120 & 100.00 \\
\hline
\end{tabular}

The duration of farmers' experience in doing farming is affecting the adoption of innovation (Soekartawi, 2008). Researchers argued that the longer duration of farmers in doing farming helps farmers to learn from the experience and mistakes they had before (Murwanto, 2008). However, the data of this study proved that the long duration of farmers' experience could be an obstacle to adopting innovation. More than $40 \%$ of respondents had experience in cattle for 1114 years. Farmers with a long duration of experience have a farming pattern, that has been done for years and even pass on to every generation. Therefore, in some cases, farmers experienced difficulties to change traditional practices and adopt innovations.

\section{Extension agents}

The selection of the right extension agents and communication channels affecting the adoption of innovative technology (Bakhtiar \& Novanda, 2018). A previous study showed that farmers in Indonesia received information related to 
technology and innovation from the government, academic institutions, and other farmers (Guntoro, Rakhman, \& Suranindyah, 2016). Extension agents in this study were divided into two groups: 1. Extension Agent Team from Faculty of Animal Science Universitas Brawijaya

The team from the Faculty of Animal Science Universitas Brawijaya introduced the implementation of Artificial Insemination using Frozen Sexed Semen and double straw methods. With this technology, female cattle were inseminated with two straws of frozen sexed semen at different times. The first insemination was given 8 hours after the estrous sign was reported by farmers and the second insemination was given 16 hours after the estrous sign was reported by farmers. Laboratory research proved that using the FSSAI increased the chance for male calve birth. The purpose of using FSSA was to cattle farmers improving the efficiency of cattle farming.

However, in practice, technology, and innovation tested on a laboratory scale could be different from the implementation in the community. Therefore, extension agents should acknowledge some points:

a) The agents recognize that the extension program is a two-way education process. The extension process is not only to share innovation or new information related to the technology to farmers but also it is a chance for the researcher to test the implementation of the technology in the real world. This opportunity gives more information for the researcher to revise or adjust the technology to meet the need of the community in addressing real challenges in the future time.

b) Repeat information is needed to communicate or inform the technology and innovation to respondents. This is important especially with the vary of age, education level, background, and experiences of targeted respondents. Repeat information is also needed to provide time for respondents to understand and rethink the benefit of the technology and innovation before they decided to adopt or reject the innovation.

c) Local counterparts are needed to be the agent of change in the community and help to diffuse the information to the broader community members. In this case, the team from University of Brawijaya was not part of the local community and they did not have enough time to stay and repeat the information regularly to the respondents. Therefore, the collaboration with local counterparts such as inseminators helped out the diffusion process to inform the technology to targeted respondents.

2. Inseminators.

Inseminators are government licensed officers who had a responsibility to the insemination process in the community. In this project, the inseminator was part of the community member and he has been a senior inseminator for quite a long time in the community. Therefore, he knew more about the people, the culture, challenges, and problems related to cattle beef farming in Palang Village. Another role of inseminators in the community is explaining factors supporting the success of Artificial Insemination, including feeding management, the Body Condition Score (BCS), and perfect timing for Artificial Insemination.

Moreover, in this study case, farmers trusted inseminators to choose the breed type of straws using for the Insemination, the technique used for the AI implementation (thawing, vitamin, and AI position), and AI timing. This is showing that inseminators play an important role to interact with farmers and disseminate new technology to the community. Qualitative data supported this that up to $45 \%$ of respondents stated that they relied on inseminators as the source of information. Direct counseling is one of the effective ways to increase knowledge and decisions to adopt innovative technology (Bakhtiar \& Novanda, 2018). 
Table 8. Resources of information related to AI

\begin{tabular}{ccc}
\hline Source of infromations & Number of respondents & Percentage (\%) \\
\hline News & 2 & 1.67 \\
Family & 5 & 4.17 \\
Extension agents/inseminators & 54 & 45.00 \\
Neighbor & 59 & 49.17 \\
\hline Total & 120 & 100.00 \\
\hline
\end{tabular}

Respondents in this research were categorized as, early majority adopters. This means that they will adopt the technology if it has been proven. Table 8 showed that more than $49 \%$ of respondents stated that information related to AI they got from neighbors. The other $45 \%$ informed that the main resource of $\mathrm{AI}$ information was from extension agents/inseminators. This confirms that respondents on the research believed information from closed related and trusted people such as neighbors and inseminators. Respondents also trusted innovation or technology that they have seen the result. Moreover, the majority adopter respondent needs to receive the information frequently, as information provided by inseminators. This is in line with Agustine et al (2019) that some farmers do not know the breed inseminated into their cow, they only follow the inseminator as their opinion leader.

\section{CONCLUSIONS}

In conclusion, research of this study proved that innovation, characteristics of respondents, and extension agents play important role in affecting the technology and innovation adoption level of respondents. Based on technology and innovation, the success of AI implementation is more important for respondents compare to the sexing of calves. Moreover, the characteristics of respondents also an important factor to increase the chance of the adoption level of the community.

\section{REFERENCES}

Adegbola, P., \& Gardebroek, C. (2007). The effect of information sources on technology adoption and modification decisions. Agricultural Economics,
37(1), 55-65. https://doi.org/10.1111/ j.1574-0862.2007.00222.x

Afiati, F., \& Said, S. (2013). Pembibitan

Ternak dengan Inseminasi Buatan.

Penebar Swadaya Grup.

Agustine, R., Bintara, S., Andarwati, S., Widi, T. S. M., \& Putra, A. R. S. (2019). Farmer's decision in selecting the bull semen for artificial insemination in Central Java. IOP Conference Series: Earth and Environmental Science, 260. https:// doi.org/10.1088/1755-1315/260/1/01 2048

Bakhtiar, A., \& Novanda, R. R. (2018). The relationship between the adoption innovation and the communication channel of madura cattle farmers. Journal of Socioeconomics and Development, 1(2), 72. https://doi. org/10.31328/jsed.v1i2.604

BPS-Statistics Indonesia. (2020). Distribusi Perdagangan Komoditas Daging Sapi di Indonesia 2019.

Bryman, A. (2012). Social Research Methods (Vol. 4th). Oxford University Press.

Eddy, B. T., Roessali, W., \& Marzuki, S. (2012). Dairy cattle farmers' behaviour and factors affecting the effort to enhance the economic of scale at getasan district, Semarang regency. Journal of the Indonesian Tropical Animal Agriculture, 37(1). https:// doi.org/10.14710/jitaa.37.1.34-40

Ervandi, M., Ihsan, M. N., Wahjuningsih, S., Yekti, A. P. A., \& Susilawati, T. (2020). Relationship between body condition score on the service per conception and conception rate of Brahman Cross cows. Jurnal IlmuIlmu Peternakan, 30(1), 80-85. https://doi.org/10.21776/ub.jiip.2020. 
030.01 .08

Ghozali, I. (2013). Aplikasi Analisis Multivariate Dengan Program SPSS. Badan Penerbit Universitas Diponegoro.

Guntoro, B., \& Priyadi, R. (2013). Motivation and performance of beef cattle smalholder farmer in Central Java, Indonesia. Jurnal Internasional, 6(4-6), 85-89.

Guntoro, B., Rakhman, A. N., \& Suranindyah, Y. Y. (2016). Innovation adoption of dairy goat farmers in Yogyakarta, Indonesia. International Journal of Environmental \& Agriculture Research (IJOEAR), 2(2), 98-109.

Jemal, H., \& Lemma, A. (2015). Review on major factors affecting the successful conception rates on biotechnological application (AI) in cattle. Global Journal of Medical Research, Massachutsetts, 15(3), 19-27.

Liamputtong, P. (2013). Qualitative Research Methods (Vol. 4th). Vic: Oxford University Press.

Murwanto, A. G. (2008). Karakteristik peternak dan tingkat masukan teknologi peternakan sapi potong di Lembah Prafi Kabupaten Manokwari. Jurnal Ilmu Peternakan, 3(1), 8-15.

Roessali, W., Masyhuri, M., Nurtini, S., \& Darwanto, D. H. (2011). Factors influencing farmers' decision to increase beef cattle business scale in Central Java Province. Journal of the Indonesian Tropical Animal Agriculture, 36(1). https://doi.org/10. 14710/jitaa.36.1.27-35

Sall, S., Norman, D., \& Featherstone, A. . (2000). Quantitative assessment of improved rice variety adoption: the farmer's perspective. Agricultural Systems, 66(2), 129-144. https://doi. org/10.1016/S0308-521X(00)00040-8
Sarantakos, S. (2005). Social Research (Vol. 3rd). Palgrave Macmillan.

Setiana, L., Saleh, D. M., Nugroho, A. P., \& Lana, D. L. (2020). Factors in the Adoption of beef cattle artificial insemination (AI) technology in Brebes Regency. Jurnal Penyuluhan, 16(1), 16-23. https://doi.org/10.25 015/16202027574

Sirajuddin, S. N., Sudirman, I., Bahar, L. D., Al Tawaha, A. R., \& Al Tawaha, A. R. (2018). Social economic factors that affect cattle farmer's willingness to pay for artificial insemination programs. Bulgarian Journal of Agricultural Science, 24(4), 574-580.

Sirajuddin, S. N., Sudirman, I., \& Bahar, L. D. (2018). Relationship between breeder characteristics and adoption of artificial insemination in Bali Cattle. European Journal of Sustainable Development, 7(3), 143-150. https:// doi.org/10.14207/ejsd.2018.v7n3p143

Soekartawi. (2008). Prinsip Dasar Komunikasi Pertanian. UI Press.

Susilawati, T. (2014a). Pedoman Inseminasi Buatan pada Ternak. Universitas Brawijaya Press.

Susilawati, T. (2014b). Sexing Spermatoza: Hasil Penelitian Laboratorium dan Aplikasi pada Sapi dan Kambing. Universitas Brawijaya Press.

Susilawati, T. (2019). Klaster Sapi Potong. Universitas Brawijaya Press].

Wahjuningsih, S., Susilawati, T., Ihsan, M. N., Busono, W., Isnaini, N., \& Yekti, A. P. A. (2019). Teknologi Reproduksi Ternak. Universitas Brawijaya Press.

Walter, M. (2013). Social Research Methods (Vol. Thirdition). Oxford University Press.

Yin, R. K. (2013). Case Study Research: Design and Methods. SAGE Publications. 